\title{
Концепция и эталонная модель свободной геолого-геофизической программной платформы
}

\section{Дегтерёв А.Ю. ООО Газпром ВНИИГАЗ}

K настоящему времени накоплено достаточное количество свидетельств пагубного влияния концепции закрытого программного обеспечения на образование, науку, государственную безопасность и другие сферы человеческой деятельности, затронутые информатизацией. Одновременно с этим, с каждым годом получает всё большее признание концепция свободного программного обеспечения (СПО), лишённая её недостатков. Преимущества данной концепции настолько существенны, что реализующие её свободные проекты находят поддержку не только частных лиц, коммерческих и общественных организаций, но и государственных структур многих стран. Ряд стран оказывает поддержку международным свободным проектам, некоторые страны — в том числе и Россия — развивают национальные проекты на принципах СПО.

В самых разных предметных областях свободные решения составляют всё более серьёзную конкуренцию своим закрытым аналогам, постепенно вытесняя их и занимая лидерские позиции. Вместе с тем, в области геолого-геофизических задач наблюдается существенное отставание развития свободных проектов, что, по-видимому, обусловлено как спецификой взаимоотношений между субъектами данной отрасли, так и спецификой решаемых задач. Несмотря на очевидные проблемы, связанные с наблюдаемым отставанием, его положительной стороной является возможность анализа опыта других областей и заблаговременного построения эталонной модели целевой свободной геолого-геофизической программной платформы. Использование единой эталонной модели необходимо, чтобы на всех этапах существования проекта обеспечить взаимопонимание между участниками процесса: основным коллективом разработчиков, разработчиками-энтузиастами, пользователями, государственными структурами, частными инвесторами и другими заинтересованными сторонами. Взаимопонимание, необходимое для развития единой платформы, позволит в будущем избежать фрагментации создаваемых свободных проектов и авторских коллективов, и возникающей при этом разнородности рабочих спецификаций развиваемых ими систем.

В докладе представлена концепция и эталонная модель свободной геолого-геофизической программной платформы, приводятся предпосылки, обусловившие необходимость её разработки, рассматриваются вопросы экономической целесообразности разработки СПО с учётом опыта отечественных и зарубежных проектов. 